\title{
Overview of Major Industries in Bangladesh
}

\author{
Ahaduzzaman, Prottasha Sarkar, Aniqa Anjum and Easir A Khan \\ Department of Chemical Engineering, Bangladesh University of Engineering and Technology (BUET), \\ Dhaka-1000, Bangladesh
}

\begin{abstract}
Industrialization is an essential prerequisite for rapid economic growth of a developing country like Bangladesh. This study shows the major industrial growth of the country and their impact on the national economic development, public safety, health and environment. The capacity, productivity and export/import values of industrial products are used to establish the baseline scenario. There are significant numbers of chemical intensive industries such as textile, leather, food, fertilizer and pharmaceutical industry that have direct impact on socio economic development of the country. It is worth noting that Bangladesh is not only importing industrial products from other countries but also exporting a substantial amount of product to over 100 countries of the world and shows an impressive growth in industrial sectors Rapid industrial growth often offers a huge burden of environmental pollution and associated risks. Thus, there are still lots of space for Bangladesh to flourish in this sector. This study presents the prospects, and recommendations for major industrial sectors to achieve safe and sustainable industrial growth in Bangladesh.
\end{abstract}

Keywords: Industrialization, Environmental Pollution, Export \& Import, Safety and Sustainability

\section{Introduction}

Bangladesh is a developing country in the world. The economic development is largely dependent on the industrial advancement of a country. Industrializations have a great contribution to minimize the unemployment problem in this country and can raise social productivity by producing goods on a mass scale[1]. The gross economy of is increasing with the industrialization in Bangladesh. It proves that industries have a great contribution on the country economy. No country in the world is self-sufficient in the production of all types of goods and services. Every country has to import to meet the demand of its own. Bangladesh is no exception to that. Bangladesh has production deficit in necessary equipment's, medicine, vehicles and imported these from foreign countries. At the same time, Bangladesh is producing garments, pharmaceuticals, cements and many other goods excessively after meeting her demand. So it is understood that Bangladesh can meet its deficit by importing goods and can export her excess produced goods after meeting up own demand. Poor countries like Bangladesh can earn valuable foreign exchange by exporting manufactured products and the foreign exchange can be used to invest in newer machines and technologies so that a rapid growth of industry becomes possible. Bangladesh is the 54th largest importer and 55th largest export economy in the world as reported in 2015 [11]. During the last five years the imports and exports of Bangladesh have increased at an annualized rate of $8.7 \%$ and $11.9 \%$ respectively [11]. This market research report offers a perspective on the actual market situation, trends

*Corresponding author: Dr. Md Easir Arafat Khan

Email: eakhan@che.buet.ac.bd and future outlook for chemical in Bangladesh. The study is mainly based on secondary sources of data which was collected from various books, journals, research works, publications etc. The study provides essential market information for decisionmakers for the related business personnel including.

- To gain an in-depth understanding of industrial markets in Bangladesh.

- To identify the ongoing trends of different industrial sector in Bangladesh.

- To examine the contribution of industrial sector in the national economy.

\section{Industrial Sectors in Bangladesh}

Instead of being a developing country, almost onethird of her population is under extreme poverty. Bangladesh has one of the largest populations in the world with over 162 million inhabitants (as of 2016). [15] Due to Bangladesh's relatively small land mass, its population density is also one of the highest in the world; with more than 1,200 inhabitants per square $\mathrm{km}$. There is different type of industries in Bangladesh, although the productivity growth that comes from industrialization depends on the growth of high-value-adding modern industries, most of the firms in the industrial sector in Bangladesh are small-scale or traditional cottage industries. They are often firms in the informal sector, which means that these firms are too small to come under the regulatory structures of the state. Because of the development in RMG sector and microcredit, GDP growth rated are above 5 percent in the last decade. Bangladesh has a growing economy, having maintained a steady GDP growth averaging above 6 percent since 2010. As in 
most growing economies, contribution of the Agriculture sector to GDP has been on a steady decline, with Services making up most of GDP, followed by the Industries sector. Bangladesh operates a thriving textile and clothing export industry and is one of the world's largest garment exporters. Garments account for almost 80 percent of its total exports. [16] Large-scale industries are also likely to enjoy faster productivity growth compared to small-scale and cottage industries. Productivity is a measure of the output produced in that industry and productivity growth measures the rate of growth chemicals import and use. There are various types of industries in Bangladesh. The average growth rate of industries is on average 6$10 \%$. Chemical and pharmaceutical, power, food and allied industries have major share in numbers as shown in Fig.1.

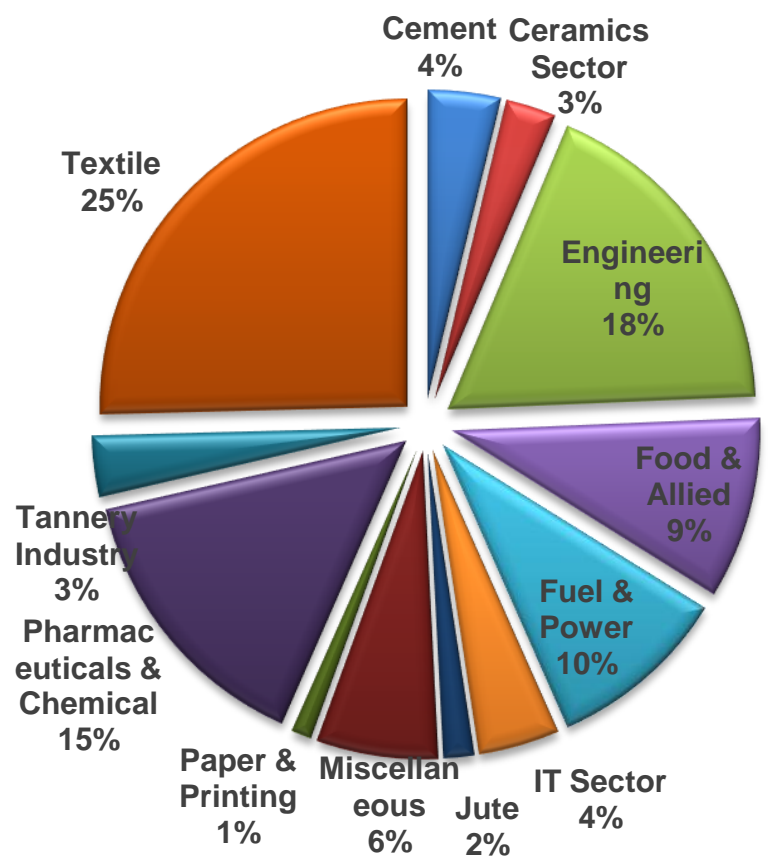

Fig.1. Percentage of Sector Wise Industries in Bangladesh [17]

\section{Status of Industrial Growth}

Since its independence in 1971, Bangladesh has achieved a tremendous growth rate in its industrial production. The economy comprises of a number of Small and Medium Enterprises that make up for $25 \%$ of the nation's Gross Domestic Product (GDP). Three products like garments, pharmaceuticals and textiles constitute $65 \%$ of manufacturing growth. [18] In the 1960s and 1970s, it was widely believed by international economists that the state had to play a direct role in industrial development. The reconstruction and rehabilitation cost of the damaged industrial units after liberation war was estimated at Taka 291 million, of which Tk. 223 million was estimated for the public-sector industries. The journey of the nationalized industrial sector began in 1972 with 72 jute mills, 44 textile mills, 15 sugar mills, 1 still mill, a diesel engine unit and a shipbuilding industry. However, all these industries turned into loosing concerns very soon due to mainly mismanagement and secret removal of wealth and capital. The development of new industries like sulfuric acid, chemicals, paper, caustic soda, glass, fertilizer, ceramic utensils, cement, still and engineering was slow before 1985.New industrial ventures set up in the 1980s in Bangladesh have been playing a significant role in the country's economy. These include, shipbuilding industry, motor vehicle assembling plant, oil refinery, insulator and medical equipment manufacturing factories, telephone and telecom accessories making units, televisions assembling factories, cigarette factory and vegetable oil industries. Readymade garment sector achieved a remarkable progress in the country during the period. Policy comprising national development plan and open market economy have been followed by the government, resulting in significant industrial growth in the 1990s[19]. Since then the industrial growth is remarkable except some obstacle in few years. The clear picture of the industrial growth form financial year 1998 to 2016 is shown in Fig. 2.

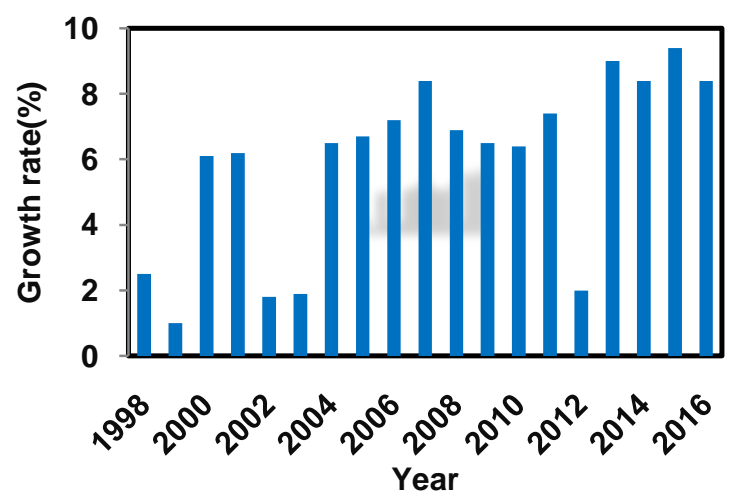

Fig.2. Industrial growth rate of Bangladesh

\section{Major Industrial Sector in Bangladesh}

Bangladesh is populated country in the world. The economic stability of this country is largely dependent on agriculture. But the economic income from agriculture sector cannot fulfill country's all requirements. Industrialization is a better solution to economic development for the highly populated country like Bangladesh. So, the economic policy has been changing from agriculture sector to industrial sector in last few years. The growth rate of industry in different sector is quite satisfactory. The analysis of some major industry in Bangladesh is described below:

\subsection{Garments Industry}

The Ready Made Garments (RMG) is covering a large industrial sector in Bangladesh. In 1994, there were only 300 factories employing only a few 
thousand people. The number of RMG factories is increasing in almost every year. From Fig.3, it can be said that the RMG sector has experienced an exponential growth since the 1984 [20]. The exponential growth rate is continuing up to $2013 \mathrm{~s}$. After that the exponential growth is disturbed due to some incident happen in this sector. Government and private sector took necessary steps to solve the major problems in this sector. The problems have been little bit overcome in last few years. The growth rate is staring to increase again. Currently, there are 4296 manufacturing units and large number of factories is in under construction.

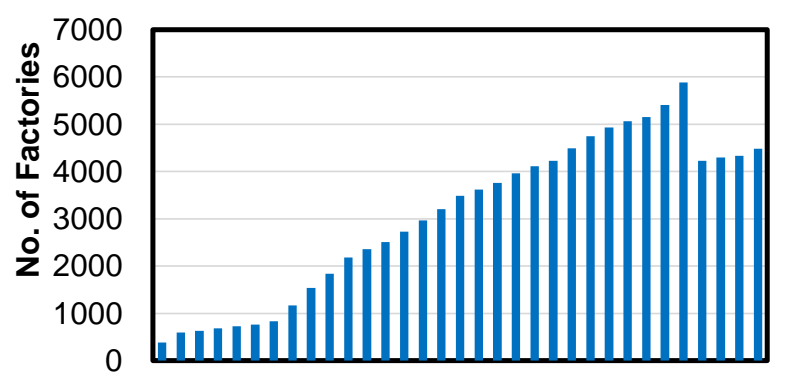

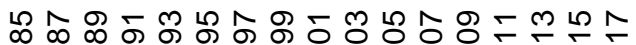
等 品 \% Year

Fig.3. Growth of RMG Factories in Bangladesh [8]

The Ready Made Garments (RMG) sector has emerged as the biggest earner of foreign currency and has a great contribution to increase Gross Domestic Product (GDP) in Bangladesh. In the financial year 2014-15, RMG has made the $81.69 \%$ contribution of total earning foreign currency of USD 31.2 billion by exporting various goods. In the current financial year 2019-17, Bangladesh export USD 28.67 billion which is $7.76 \%$ higher than the previous calendar year[13]. The growth rate of RMG and total exporting currency are shown in Table 1.

Table 1: Value of total exporting currency from RMG sector and RMG growth rate in calendar year basis [13]

\begin{tabular}{ccc}
\hline Year & million USD & Growth (\%) \\
\hline 2007 & 9350.33 & 4.67 \\
2008 & 11878.92 & 27.04 \\
2009 & 11890.49 & 0.10 \\
2010 & 14854.6 & 24.93 \\
2011 & 19214.47 & 29.35 \\
2012 & 19788.14 & 2.99 \\
2013 & 23500.98 & 18.76 \\
2014 & 24583.96 & 4.61 \\
2015 & 26602.7 & 8.21 \\
2016 & 28668.29 & 7.76 \\
\hline
\end{tabular}

It can be said by analyzing the data of Table 1 and Fig.3, RMG sector in Bangladesh have been securing a high growth in every year. The exporting currency from this sector is also increasing in every calendar year. The average growth form the financial year 2007 to 2016 is $12.84 \%$ which shows strong potential of the sector. Proper infrastructure and more investment in this sector are needed to reach its expected growth.

Large number of worker is needed in garments industry. So increase the number of garments industries in Bangladesh can decreases the unemployment problems in the country. Proper maintenance in this sector can make leading textile exporter country in the world.

\subsection{Chemical Industry}

Chemical is very useful commodities in everywhere. Huge amount of chemical is necessary in the everyday life. The use of chemical is increasing day by day in the large populated country like Bangladesh. Though the number of chemical industry is creasing but the growth rate of chemicals industry is unsatisfactory. Bangladesh is fulfilling the requirements by importing chemicals from other countries. Only few chemicals industries such as Chlor-Alkali Plant and its Chlorinated product and Hydrogen peroxide plant are the main basic chemical industry in Bangladesh. The products from these basic chemicals Industries are Caustic Soda $(\mathrm{NaOH})$, Chlorine $\left(\mathrm{Cl}_{2}\right)$, Hydrochloric Acid $(\mathrm{HCl})$, Sodium Hypochlorite ( $\mathrm{NaOCl}$ ), Stable Bleaching Power (SBP), Chlorinated Paraffin Wax (CPW) and Hydrogen Peroxide $\left(\mathrm{H}_{2} \mathrm{O}_{2}\right)$ [2]. There are some local chemical company who took challenge in this sector. ASM Chemical Industries Ltd., Global Heavy Chemicals Ltd, Samuda Chemical Complex Itd., Tasnim Chemical Complex and HP Chemicals Ltd. are playing a vital role to increase chemical production in this country. Tasnim Chemicals Ltd. is the latest technological industry and produce largest amount of Hydrochloric acid and Caustic soda among others companies. Samuda Chemicals Ltd. and ASM Chemicals Ltd. are also producing large amount basic chemicals. HP Chemical Ltd. is a new and small chemical industry where only Hydrogen peroxide is produced. The total daily production capacities of the basic chemicals are mentioned in Table 2. The different chemical industries can produce maximum 800 metric ton per day hydrochloric acid and minimum 42 metric ton per day liquid chlorine. All of the companies are trying to increase their production capacity to fulfill the local demand of basic chemical consumption.

Production capacities of Basic Chemicals in different Chemical industries of Bangladesh are given below in Table 2 . 
Table 2. Production Capacity of Basic Chemicals in Different Chemical Industry of Bangladesh [2].

\begin{tabular}{lcccccc}
\hline Product Name & $\begin{array}{c}\text { ASM } \\
\text { Chemicals } \\
\text { (MT/day) }\end{array}$ & $\begin{array}{c}\text { Global } \\
\text { Chemicals } \\
\text { (MT/day) }\end{array}$ & $\begin{array}{c}\text { Samuda } \\
\text { Chemicals } \\
\text { (MT/day) }\end{array}$ & $\begin{array}{c}\text { Tasnim } \\
\text { Chemicals } \\
\text { (MT/day) }\end{array}$ & $\begin{array}{c}\text { HP } \\
\text { Chemicals } \\
\text { (MT/day) }\end{array}$ & $\begin{array}{c}\text { Total } \\
\text { Production } \\
\text { Capacity } \\
\text { (MT/day) }\end{array}$ \\
\hline $\begin{array}{l}\text { Caustic Soda (100\% basis } \\
\text { Flake/Liquid) }\end{array}$ & 60 & 70 & 60 & 100 & - & 290 \\
$\begin{array}{l}\text { Chlorine }\left(\left(\mathrm{Cl}_{2} \text { From }\right.\right. \\
\text { Electrolizer) }\end{array}$ & 53 & 62 & 53 & 89 & - & 257 \\
$\begin{array}{l}\text { Hydrogen Peroxide (50\% } \\
\left.\text { Conc, } \mathrm{H}_{2} \mathrm{O}_{2}\right)\end{array}$ & 60 & - & 70 & 60 & 28 & 218 \\
Chlorine $\left(\mathrm{Cl}_{2}\right)$ liquid & 10 & 10 & 7 & 15 & - & 42 \\
$\begin{array}{l}\text { Hydrochloric Acid (32\% } \\
\text { HCl) }\end{array}$ & 220 & 200 & 100 & 280 & - & 800 \\
$\begin{array}{l}\text { Sodium Hypochloride } \\
\text { (NaOCl) }\end{array}$ & 10 & 10 & 20 & 15 & - & 55 \\
$\begin{array}{l}\text { Stable Bleaching (SBP) } \\
\text { Chlorinated Paraffin wax }\end{array}$ & 20 & 15 & 16 & - & - & 51 \\
(CPW) & 20 & 10 & 20 & 15 & - & 65 \\
\hline
\end{tabular}

Bangladesh is not chemically developed country. The raw materials to produce the basic chemicals as well as other chemicals are also imported from other country. From Fig.4, it is observed that China has been leading as the top chemical importing country for Bangladesh for the economic year 2007 to 2015. Side by side Bangladesh has been also importing chemicals from India, Singapore and United States along with many other countries.

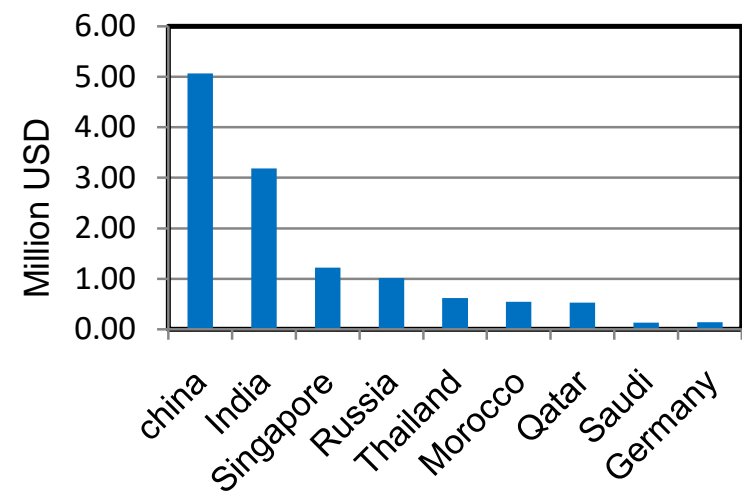

Fig.4. Top Chemical Importing Country from 20072015 [27].

In Bangladesh, the value of chemical imports has always been greater than the value of chemical exports. For this reason, the balance of trade is not favorable of Bangladesh. This has resulted in sustained fall in the external value of our currency, which means a steady increase in exchange rate over the whole period.

Bangladesh is exporting chemicals to many different countries. From 2007-2015, India has been having the maximum percent share of the chemicals being exported from Bangladesh. Other remarkable countries in this regard are Australia, Thailand, United Kingdom etc[27].

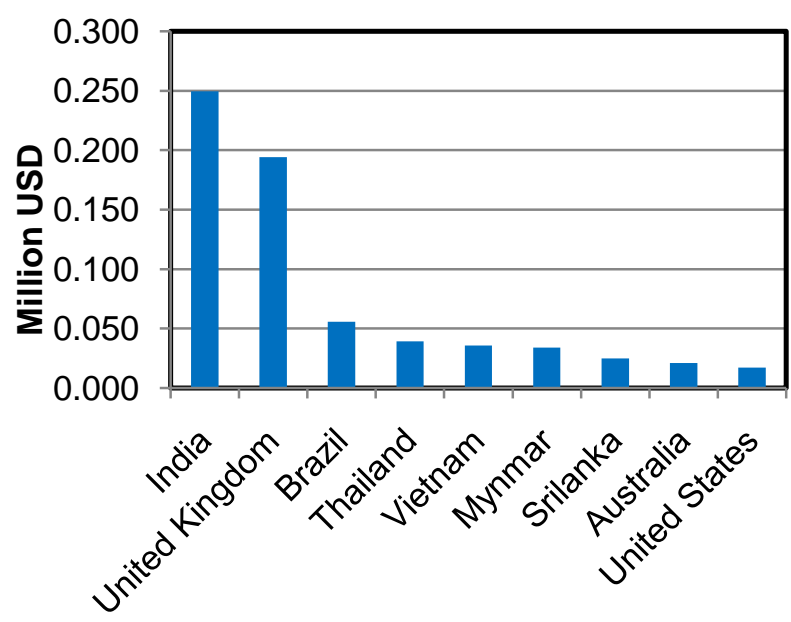

Fig.5. Top Chemical Exporting Country from 2007 2015 [27].

\subsection{Pharmaceutical Industry}

The most developed and hi-technological sector in Bangladesh is the pharmaceutical industry within the country's economy. The number of hitechnological pharmaceutical industry is increasing day by day. There were only 210 licensed allopathic drug-manufacturing units in the country in 2000 [3]. Now about 300 pharmaceutical companies are operated and manufactured about 5,600 brands of medicines in different dosage forms. The development of this sector was accelerated by the professional knowledge and ideas of the renowned pharmacist in this country. They are working very hard to produce top class drug among the world. Recently, the pharmaceutical industry is starting to 
export medicines to global markets of 79 countries, including the European market. The main exported commodities are Tablets, Capsules, Syrups including high-tech specialized products like HFA Inhalers, CFC Inhalers, Suppositories, Nasal Sprays, Injectables, IV Infusions, etc.

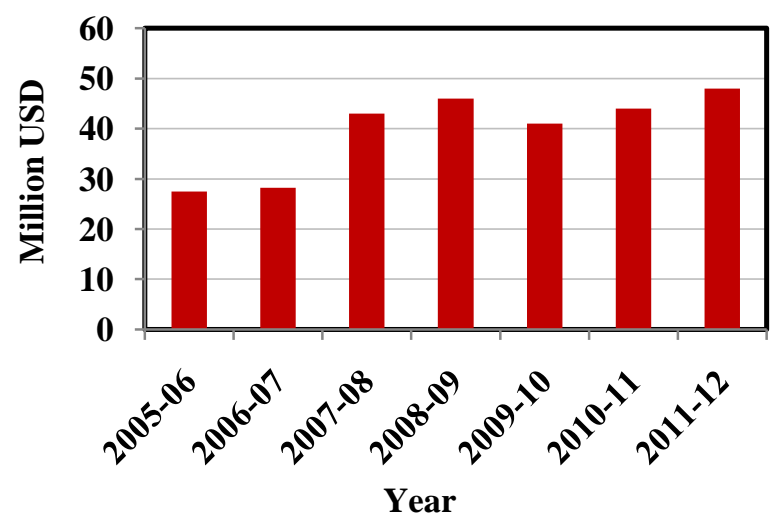

Fig.6. Exported Pharmaceutical products in million USD from 2005-2011[3].

Bangladesh has become a drug exporting country. The exporting foreign currency is increasing day by day from this sector. Bangladeshi pharmaceutical exports totaled USD 27.5 million in the financial year 2005-2006. Figure 6 has shown that the trend of the export amount is increasing in almost every year and reached to USD 48.3million in financial year 2011-12.Exports of pharmaceutical products from Bangladesh are still small in scale. It is important to take necessary steps to export pharmaceuticals in large scale.

\subsection{Tannery Industry}

Bangladesh is relatively small compared to the other big players in the world leather market, but has potential for growth, both as a consumer and as an exporter. Bangladesh's leather is widely known for its high qualities of fine grain, uniform fiber structure, smooth feel and natural texture. The leather industry is one of the oldest in the country. It is paving its ways towards gaining larger international market share by providing more value added goods. The country is blessed with a large supply of raw materials and inexpensive labor. The annual production capacity of raw materials is estimated to be around 750 million sq. ft.[12].

Currently, there are around 113 tanneries, annually producing around 300 million sp. $\mathrm{ft}$. of leather; more than $75 \%$ of which is exported in currency USD 1.1 billion which is roughly $0.5 \%$ of the global market [12].Moving in the production of value added products the industry can earn higher revenue. The industry currently has over 3,500 companies of various sizes producing these leather products. The country has been exporting more leather footwear and other leather products. Top leather exporting countries from Bangladesh are China, Japan, Germany, UAE. The Fig.7 has shown the amount of leather export to different countries in currency of million USD.

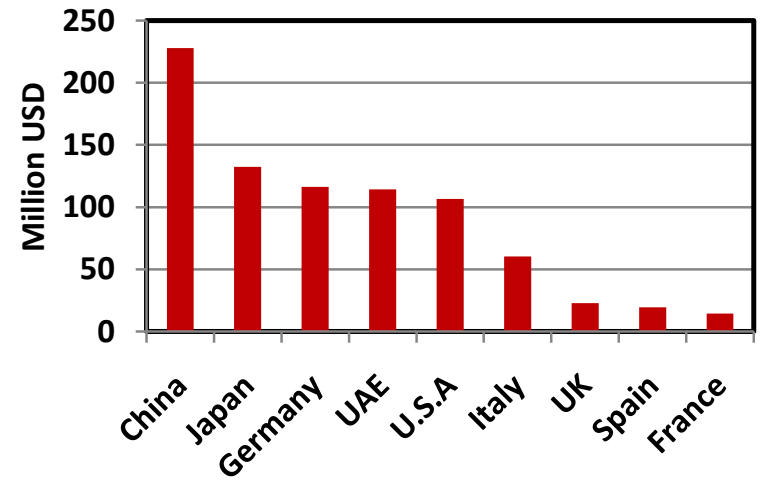

Fig.7.Top Lather exporting country of Bangladesh in last 6 years from 2010 to 2016[12].

Beside the export market, the local market is also booming. The economic growth of Bangladesh has been impressive over the last decade, despite multiple challenges affecting the economy. Rising GDP and slowing population growth have contributed to rising per capita income exceeding lower income threshold. This has resulted in a gradual increase in consumer spending over the previous years.

\subsection{Cement Industry}

Cement industry is the oldest industry in Bangladesh. The production capacity is large enough so that it is exported to other countries after filling their local demand. It is clearly shown in Fig.8, the local demand of cement is nearly two-third of the total capacity in every year from 2005- 2014. In 2014, the total capacity of the factory had been 28 million MT which is 3 million MT higher than previous year. On the other hand, in the same year the total consumption stood at 17.5 million MT which is 1.5 million MT higher than the previous year. So far, several Bangladeshi manufacturers have exported their own brands to West Bengal of India and Myanmar. According to data from Bangladesh Export Promotion Bureau, it confirms that cement exports had witnessed a 21 percent increase in the first seven months of financial year 2012 [7]. In view of the situation, recently some local producers visited Sri Lanka, Myanmar and some of South African countries on market-exploration mission. Moreover, every year on an average $180000-240000$ MT of cement is being exported by the industry [5]. 


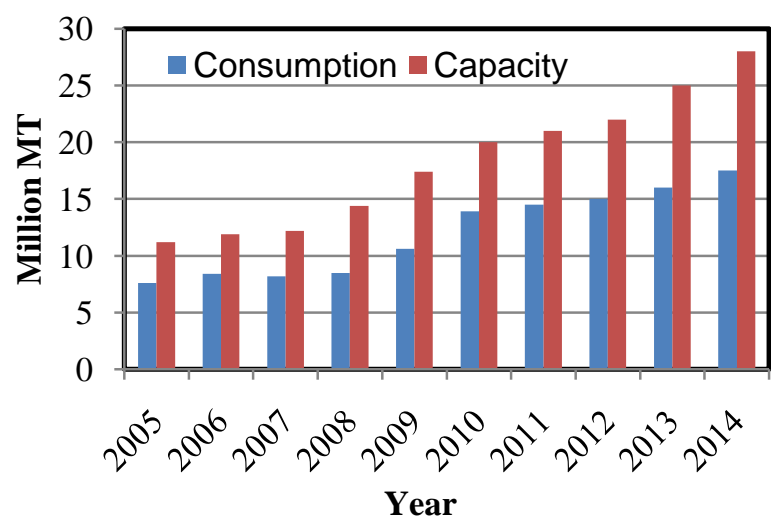

Fig.8. Cement production and consumption in Bangladesh from 2005-2014 [4].

\subsection{Food industry}

Food is very important commodities in every human being. So, it is very necessary to grow large number of food processing industries for every nation. The food processing industry in Bangladesh is one of the major potential sectors within the industrial segments in terms of contribution to Gross Domestic products, GDP and employment. This high potential sector employs $2 \%$ of the national GDP and accounts for over $22 \%$ of all manufacturing production [10]. The food processing sector includes different types of commodities such as Frozen food, Tea, vegetables, cereals, bakery and confectionary, fruits and vegetables, dairy, carbonated beverages and non-carbonated fruit juices, drinks and various other food items [8]. The remittance earning from other country in the economic year 2013-2014 by exporting different food commodities are given in Table 3.

Table 3: Exported different food commodities in 2013-2014 [10]

\begin{tabular}{lc}
\hline Commodities & Values in million USD \\
\hline Frozen Food & 629.77 \\
Frozen Fish & 63.55 \\
Tea & 2.62 \\
Vegetables & 128.83 \\
Cut flowers and & 44.52 \\
foliage & 93.56 \\
Fruits & 25.12 \\
Spices & 48.64 \\
Dry food & 238.83 \\
Other agro & \\
commodities &
\end{tabular}

After fulfilling the local demand, these processed products are being exported to 70 countries throughout the world. Asia, Africa, Europe are the top exporting country of Bangladesh for different types of processed food. Frozen food is the top exporting food products from Bangladesh as shown in Table 3. Vegetables, Tea, Dry food are also exported to different countries and earn large amount of foreign currency. It is difficult for highly dense country like Bangladesh to export large amount of food product due to shortage of cultivated land. Bangladesh is trying to increase the growth rate of food production by imposing modern technology in agricultural and industrial sector of food. The food processing industry in Bangladesh is now growing rapidly and opening up new opportunities in terms of investment, technology and export.

\subsection{Fertilizer industry}

Fertilizer Industry is the largest industrial sector in Bangladesh. It contributes about 16 percent of the national GDP and employs approximately 47 percent of the total labor force [28]. The annual production of fertilizer in Bangladesh is always lower than annual production. According to the Ministry of Industries, 68 percent fertilizer of total demand were imported in the financial year 2015, where maximum were urea based fertilizer. The total fertilizer production capacity and total consumption from the economic year 2007 to 2012 are shown in Fig.9.

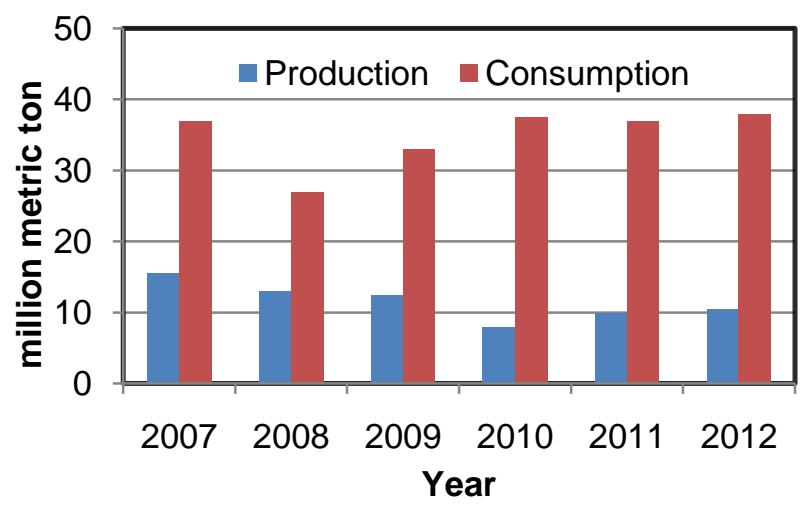

Fig.9. Fertilizer production and consumption in Bangladesh from 2007-2012 [28]

It is shown from Fig.9 that total fertilizer production is very smaller than total consumption. Though the consumption is increasing but the production is decreasing due to shortage of natural gas. the poor maintenance, exodus of experienced people, lack of human planning and above all aging of plants and obsolete technology. Bangladesh Chemical Industries Corporation operates fertilizer industries in Bangladesh. They are trying hard to increase production capacity by solving the problems.

\section{National Economic Growth}

In the year 2016 the GDP of Bangladesh was worth 221.42 billion USD. The GDP of Bangladesh contributes 0.36 percent of the world economy. The average GDP of Bangladesh is 45.68 from 1960 to 2016. The highest record is 221.42 USD Billion in 
2016 and lowest record is 4.30 USD Billion in 1960. Fig. 10 shows the GDP in Bangladesh from 2010 to 2017. The value of GDP will be over 300 Billion USD by 2020. Gross domestic product (GDP) represents the comprised value of all services and goods produced in any given year within a country. GDP is the main indicator of a country's economic condition. [22]

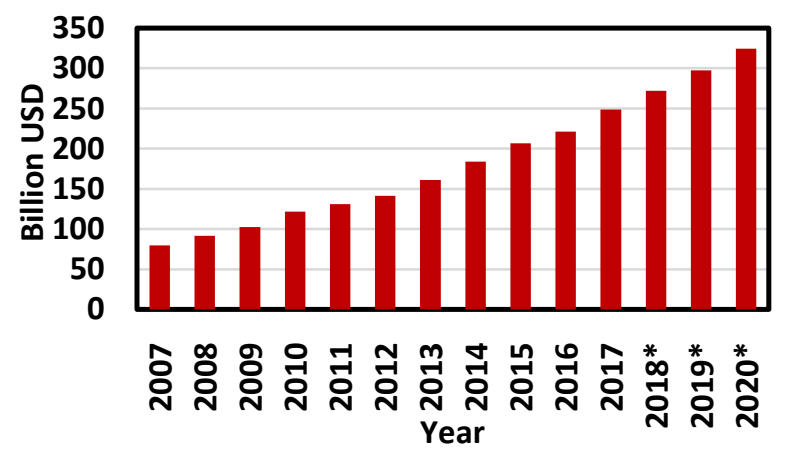

Fig.10: Bangladesh gross domestic product (GDP) 2007-2020 [23]

\section{Contribution to National Economy}

Bangladesh is a developing country with her expanding population of around 162 million. Being independent our economy is reshaped and reformed. Now, readymade garment (RMG) sector is developing quite well in comparison with other industrial sectors. It is an era of information and technology, thus various new industries have emerged. The contribution of each of those is worth mentioning.

- Agricultural contribution in our economy is the most crucial. Previously almost $85 \%$ of our people were involved in agriculture and their main way of earning was agriculture. But now along with agriculture, readymade garments (RMG), outsourcing, bank and non-bank financial institutions, exporting man power adding extra value in our economy.

- The manufacturing industry is contributing $10.1 \%$ of our GDP and agriculture $2.6 \%$ in 2015-16. Therefore, it is clear that the situation has changed than before. In total 15 types of industries are contributing in our economy now.

- All the sectors are contributing considerable amount, for example Service sector contributed total of $6.7 \%$ in $2015-16$ [24].

The value added of an industry, also referred to as gross domestic product (GDP)-by-industry, is the contribution of a private industry or government sector to overall GDP. For that indicator, The World Bank provides data for Bangladesh from 1960 to 2016. The average value for Bangladesh during that period was 19.03 percent with a minimum of 6.06 percent in 1972 and a maximum of 28.77 percent in 2016. [25] The World Bank provides data for Bangladesh value added by the industry from 1960 to 2016. The average value for Bangladesh during that period was 10.7 billion U.S. dollars with a minimum of 0.3 billion U.S. dollars in 1960 and a maximum of 60.55 billion U.S. dollars in 2016 contributed solely by industrial growth. [26]

Thus, industrial sectors are contributing huge amount of money (60 Billion USD in 2016) each year and the economic growth is mostly because of industrial growth. Also the contribution of industrial sectors to national GPD is increasing each year. It can be said that pursuing export-oriented industrialization can be beneficial for the economy of Bangladesh, focusing more in textiles, fish and seafood, shipbuilding, leather goods and jute. Considering this fact Bangladesh, Pharmaceuticals, steel and food processing industries are not dependent on other countries.

\section{Environmental Pollution and Safety}

One of major concern of the growth of industrialization is environmental pollution load from each industrial sector which greatly affects the environment as well as public health. For example only tannery sectors produces approximately 20,000 $\mathrm{m}^{3}$ of liquid waste per day and 780000 ton of solid waste. With the growth of the industries, the total pollution load is also increased. Therefore, it is high time to introduce regulatory standard and the proper waste management \& control technology for each sector. Department of Environment should play the central role to monitor and control pollution index of each sector. There are deficiencies in regulation and standard formulation and its implementation.

The concept of industrial safety is not properly addressed by the authority. Hazard analysis and risk assessment are not performed at any stages of manufacturing industries. Process safety management system has been introduced so far for process/chemical and petrochemical industry. Some of the industries has fire safety department and follow occupational safety. However, there have major deficiencies in emergency evacuation and safety drill, safety training and awareness among the employees.

\section{Prospects and Recommendations}

Bangladesh needs well planned strategies to overcome all obstacles and increase production in export sectors after filling the local demand. It is the prime mover in the development cycle in a densely populated country like Bangladesh. There are some recommendations which can be help to increase the 
industrial growth rate in a great extent and become developed country in the world.

- Government and private sectors are required to take necessary steps to develop different type of industry in Bangladesh

- Appropriate Policy can play an important role to improve export and import trade in the country

- Ensuring maximum use of local raw materials in the production of exported goods

- Import alternative industry like local raw material based industries should be established to reduce import expenditure

- Proper land use planning and relocating the industry in suitable place where experienced workers are available in lower amount wage

- Modern energy efficient and cleaner technology should be taken to increase the industrial productivity

- Safety system must be improved to prevent any potential catastrophic industrial disaster.

- Process safety management (PSM) for process industries should be adopted by the regulatory authority and be implemented by the industries to ensure safe and sustainable productivity.

\section{Conclusion}

Current industrial growth has clearly shown significant influences on national economy and development in Bangladesh. The recent trends of different indicators that are considered in measuring the development of industrial sector appear to be satisfactory. This analysis indicates that Bangladesh will be going forward to developed country from developing country if the country catch-up the current trend of industrial growth. However, the development should not be come out at the cost of environment, health and safety. Government must formulate appropriate regulatory standards, monitor and control pollution index of individual industries. Industries should adopt energy efficient and cleaner technology to ensure sustainable productivity. Proper safety awareness program, training, safety drill, fire safety, emergency evacuation and process safety management program for appropriate industries need to be introduced by regulatory authority and the owner of the industries.

\section{References}

1. M. A. Rashid Sarker, "Prospects and Challenges of Industrialization in Bangladesh," in MS.c Thesis, November 2005.

2. [Md. Sultan Salauddin, "Prospect and Challenges of Basic Chemicals Industries in Bangladesh" Journal of Chemical Engineerring, vol.ChE 26, No.1, December 2011.

3. Md. Al-Faruk, "Growth of Pharmaceutical Company in Bangladesh" in MS.c Thesis, Deffodil International University, May 2005.

4. IDLC Reasearch Report 2015: Cement Sector.
5. Royal Capital Limited. (2015). CEMENT SECTOR REPORT.

6. S. Rahman, "Cement makers eye a turnaround" in The Daily Star, October 11, 2015.

7. https://www.worldcement.com/asiapacificrim/28032012/cement_bangladesh_market/

8. Ministerial Meeting on Industry, 7th Meeting of the Working Group on Industrial Cooperation, 08-10 October 2012, Mol, GoB

9. http://www.hortex.org/Employment\%20and\% 20GDP_Agro-processed_171113.pdf

10. Annual reports of EPB 2013

11. https://atlas.media.mit.edu/en/profile/country/ bgd/\#Imports

12. [http://www.lightcastlebd.com/blog/2017/04/ leatherindustry-bangladeshs-third-engine-of-growth

13. https://www.textiletoday.com.bd/overviewbangladesh-rmg-2016/

14. Mushfica Akhter, "The Impact of Export and Import on Economic Growth in Bangladesh" in world vision, ISSN: 2078-8460, vol 9, No. 1, November 2015.

15. "The world Economy" [Online]. Available: http://www.ereport.ru/en/stat.php?razdel=country\&co unt=bangladesh\&table $=$ ipecia\&time $=2 \quad$ [Accessed: September 30, 2017]

16. "Bangladesh Garment Manufacturers and Exports Association (BGMEA)" [Online]. Available:http://www.bgmea.com.bd/home/ pages/tradeinformation. [Accessed: Sep 30, 2017]

17. Bangladesh National accounts Blue Book 2016

18. "Bangladesh: Share of manufacturing" [Online]. Available:http://www.theglobaleconomy.com/Banglad esh/Share_of_manufacturing/

[Accessed: September31, 2017]

19. "Bangladesh: Share of industry" [Online]. Available:http://www.theglobaleconomy.com/Banglad esh/Share_of_industry/ [Accessed: September 31,2017]

20. "Bangladesh: Industry value added" Available: http://www.theglobaleconomy.com/Bangladesh/indust ry_value_added/ [Accessed: September 31, 2017]

21. "Stock Bangladesh Limited" [Online] Available:http://www.stockbangladesh.com/symbols/s ectorwise [Accessed: September 31, 2017]

22. "Dhaka Stock Exchange Ltd." [Online]. Available:http://www.dsebd.org/by_industrylisting1.ph p [Accessed: September 31, 2017]

23. "Trading Economics: Bangladesh GDP". https://tradingeconomics.com/bangladesh/gdp [Accessed: September 31, 2017]

24. "Bangladesh: Gross domestic product (GDP) in current prices from 2012 to 2022 (in billion U.S. dollars)".https://www.statista.com/statistics/438219/gr oss-domestic-productgdp-in-bangladesh/ [Accessed: October 1, 2017]

25. M. N. M. Mahmud, "Current Economic Condition ofBangladesh"http://ordnur.com/economy/currenteconomic-condition-ofbangladesh/[Accessed:October 1, 2017]

26. "Bangladesh: Industry value added". http://www.theglobaleconomy.com/Bangladesh/indust ry_value_added/ [Accessed: October 1,2017]

27. https://atlas.media.mit.edu/en/profile/country/bgd/\#Im ports

28. Subrata Howlader, " Fertilizer industry in Bangladesh", Emerging Credit Rating Limited, vol 1, May 2007. 